\title{
Biological Evaluation of Anodized Biodegradable Magnesium-Calcium Alloys
}

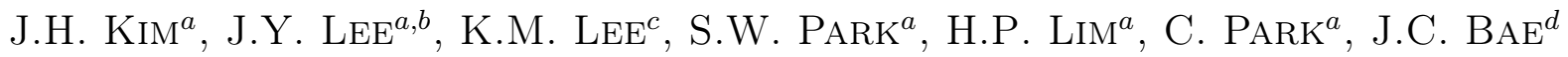 \\ AND K.D. YUN ${ }^{a, *}$ \\ ${ }^{a}$ Chonnam National University, School of Dentistry, 61186 Gwangju, Republic of Korea \\ ${ }^{b}$ Seoul Narin Dental Clinic, 62247 Gwangju, Republic of Korea \\ ${ }^{c}$ Chonnam National University, RIS Foundation for Advanced Biomaterials, 61186 Gwangju, Republic of Korea \\ ${ }^{d}$ Gwangju Technopark, 61008 Gwangju, Republic of Korea
}

\begin{abstract}
The objective of this study was to evaluate the biocompatibility of studied binary magnesium-calcium $(\mathrm{Mg}-\mathrm{Ca})$ alloys for biodegradable intraosseous implants. $\mathrm{Mg}$ is necessary for health and is a non-toxic biodegradable material that decomposes naturally in the body. Nevertheless, $\mathrm{Mg}$ has been implicated in problems including diminished physical properties and corrosion resistance when degradation is too rapid prior to bone healing. This study has explored the effect of $\mathrm{Ca}$ on the corrosion resistance and biological evaluation after anodizing treatment with different contents of Ca alloy. Binary $\mathrm{Mg}-0.5 \mathrm{Ca}, \mathrm{Mg}-1 \mathrm{Ca}$ and $\mathrm{Mg}-5 \mathrm{Ca}$ alloys were prepared by the casting method under an argon atmosphere and cut into disc-shaped pieces. Pure $\mathrm{Mg}$ alloy was used as the control. Anodic oxidation was performed for 15 minutes at a voltage of $120 \mathrm{~V}$ using an electrolyte solution containing Ca gluconate, sodium hexametaphosphate, and sodium hydroxide at room temperature. Corrosion resistance was analyzed using a corrosion tester. After a hydrogen evolution test, the surface pattern and phase changes were observed on a scanning electron microscop (SEM) and energy dispersive spectroscop (EDS). Microscopic evaluation of the adhesion and cell biological functions of $\mathrm{Mg}$ was conducted by observing the response of human fetal osteoblastic 1.19 cells with regard to changes in surface film properties, depending on the amount of Ca. Our results support the view that in $\mathrm{Mg}-x \mathrm{Ca}$ alloys $(x=0.5,1,5$ wt.\%) treated using anodic oxidation, the increasing Ca content controls the rate of decomposition and improves corrosion resistance.
\end{abstract}

DOI: 10.12693/APhysPolA.129.728

PACS/topics: 87.85.jj, 87.85.J-

\section{Introduction}

Three major factors have led to a surge in the use of bone-related treatments such as orthognathic surgery, reconstructive and cosmetic surgery, and repair of orthopedic and skeletal injuries: the increase in average life expectancy through advances in medical technology, the burgeoning interest in physical beauty and in a better quality of life, and the devastating injuries caused by industrial disasters. Operations on bone typically involve the use of bone screws, bone plates, bone fixation instruments, artificial joints, and dental implants that consist of stainless steel, titanium (Ti) or cobalt-chromium (Co$\mathrm{Cr}$ ) alloys [1]. These metal alloys are advantageous in that they are highly inert, and thus semi-permanent because of their slow elution rate in vivo, and they are associated with a decreased recovery time [2].

However, once osseointegration is complete, additional surgery may be needed to remove semi-permanent metal alloy materials because of complications including pain and chronic inflammation, distortion on computed tomographic (CT) images, dislocation of the implant separated from the bone tissue, and damage to such materials from the persistent load. For these bioinert materials to

*corresponding author; e-mail: ykd@jnu.ac.kr be used successfully in the human body, bioabsorbable metallic materials that dissolve and can be metabolized after the healing process is complete, are now being studied [1]. Magnesium $(\mathrm{Mg})$ shows great promise for use in implants because it is inherent in the human body, is nontoxic, and is a potential biocompatible and biodegradable material. Attributes of $\mathrm{Mg}$ as an excellent biomaterial include its low density, high specific strength, and resistance to fracture [3]. About $50 \%$ of $\mathrm{Mg}$ in the human body is stored in bone [4], where it promotes bone growth and increases bone strength [5]. The most attractive physical characteristic of $\mathrm{Mg}$ is its elastic modulus, which closely resembles human bone. Not surprisingly, $\mathrm{Mg}$ has been explored as bone replacement material to help prevent stress-shielding, a cause of metal implant failure [6-10].

Studies have shown that the high degradation rate of $\mathrm{Mg}$ leads to a decline in the mechanical characteristics of Mg-based implants because the hydrogen gas produced can accumulate around the implant and delay healing of the tissue $[6,11-14]$. Corrosion subsequently degrades the strength of the implant, which quickly damages the stress-bearing capacity that is crucial for the performance of implants in vivo.

Efforts to control the corrosion rate of $\mathrm{Mg}$ have included purification, alloying, anodizing, and surface coating [15]. Pure $\mathrm{Mg}$ alloy can be added to a biodegradable material $[16,17]$, and this process can enhance the 
Mg-related mechanical properties and corrosion resistance [18, 19]. Alloying elements should be non-toxic to maintain the $\mathrm{Mg}$ biocompatibility [20]. Calcium (Ca) is also a nontoxic element $[21,22]$. Mg-Ca alloys have many advantages for biomechanical use, one of which is that they accelerate bone healing by producing $\mathrm{Mg}$ and $\mathrm{Ca}$ ions [20]. These binary alloys have been established as a suitable biodegradable material for medical implants [23-25] and display excellent mechanical properties and good corrosion resistance [26]. A concern, however, may be Mg's low standard electrode potential $(-2.363 \mathrm{~V}$ NHE), which leads to rapid corrosion in the ambient atmosphere or in fluids [27, 28]. This problem can be alleviated by the process of anodizing, in which the metal is immersed in an acid electrolyte bath, and an electric current is passed through the medium, releasing oxygen to form an anodic film that promotes better adhesion [6, 29-31]. Anodizing also increases resistance to corrosion and wear and confers high electrical resistance, which helps inhibit the corrosion of $\mathrm{Mg}$-based alloys [31-35].

In this study, we have manufactured three types of $\mathrm{Mg}-x \mathrm{Ca}$ binary alloys $(x=0.5,1,5$ wt. $\%)$, and these were anodized at $120 \mathrm{~V}$ for 15 minutes to control rapid biodegradation. Corrosion resistance and biocompatibility were assessed, and the mechanism of corrosion was explored through hydrogen evolution tests in Tas-simulated body fluid (SBF) solution. Also, we reported the results of corrosion resistance testing on biological assessment of the alloys.

\section{Materials and methods}

\subsection{Specimen preparation}

$\mathrm{Mg}-x \mathrm{Ca}$ binary alloys were produced with $\mathrm{Mg}$ (99.9\%, Sincere East, China) and Ca (99.9\%, Junsei Chemical, Japan). A $15 \mathrm{~mm}$ diameter $\mathrm{Mg}$ rod was cut into discs $2 \mathrm{~mm}$ thick using an ISOMET 5000 linear precision saw (Buehler, USA) for use in corrosion resistance testing, and cell activity tests. All specimens were sequentially polished to a high number by sequential grinding using \#600 to \#2000 silicon carbide abrasive papers in a Labopol-5 grinder (Struers, Denmark), and were finally wet-ground using a $0.3 \mu \mathrm{m}$ alpha alumina $\left(\mathrm{Al}_{2} \mathrm{O}_{3}\right)$ suspension. For ultrasonic cleaning, the prepared specimens were then immersed into distilled water for 3 minutes. Any remaining organic compounds and impurities on the disc surfaces were removed to minimize their possible effects. The specimens were then dried and stored at room temperature.

\subsection{Experimental alloys}

The anodized experimental alloys have comprised three groups, based on their $\mathrm{Ca}$ content, $\mathrm{Mg}-0.5 \mathrm{Ca}, \mathrm{Mg}-1 \mathrm{Ca}$, and $\mathrm{Mg}-5 \mathrm{Ca}$ alloy, and anodized pure $\mathrm{Mg}$ was used as the control group (Table I).
TABLE I

Experimental groups.

\begin{tabular}{c|c|c|c}
\hline \hline Surface & Material & \multicolumn{2}{|c}{ Composition [wt.\%] } \\
\cline { 3 - 4 } treatment & & $\mathrm{Ca}$ & $\mathrm{Mg}$ \\
\hline \multirow{5}{*}{ Anodizing } & Pure $\mathrm{Mg}$ & - & Bal. \\
& $\mathrm{Mg}-0.5 \mathrm{Ca}$ & 0.5 & Bal. \\
& $\mathrm{Mg}-1 \mathrm{Ca}$ & 1 & Bal. \\
& $\mathrm{Mg}-5 \mathrm{Ca}$ & 5 & Bal.
\end{tabular}

\subsection{Anodizing process}

The processing of all specimens has included 3 minute ultrasonic cleaning in distilled water using a model JAC2010 ultrasonic cleaner (Kodo, Korea), acidizing, anodizing, and sealing. The sealed specimens were then cleaned three times for 10 seconds each, using reverse osmosis water to wash off the remaining solution. A VUPOWERAK6003 apparatus (ICAN, Korea) was used to supply the DC electrical current, and the specimens were anodized with $\mathrm{Mg}$ serving as the anode and a platinum plate $\left(3 \times 4 \times 0.1 \mathrm{~mm}^{3}\right)$ serving as the cathode. The anodecathode distance was $30 \mathrm{~mm}$. Calcium gluconate $(4 \mathrm{~g} / \mathrm{L})$, sodium hexameta-phosphate $(3 \mathrm{~g} / \mathrm{L})$, and sodium hydroxide $(6 \mathrm{~g} / \mathrm{L})$ were used for the electrolyte solution, with the tank solution maintained at room temperature $\left(20-25{ }^{\circ} \mathrm{C}\right)$ during the water circulation. We used a scrrectifier DC purifier (Hyun Sung Electronic, Korea) operating at DC $300 \mathrm{~V}$ and $10 \mathrm{~A}$, with anodizing carried out for 15 minutes at $120 \mathrm{~V}$. After being anodized, specimens were submerged in $100^{\circ} \mathrm{C}$ distilled water for sealing and were then dried by air blowing. Figure 1 provides a schematic of the anodizing process.

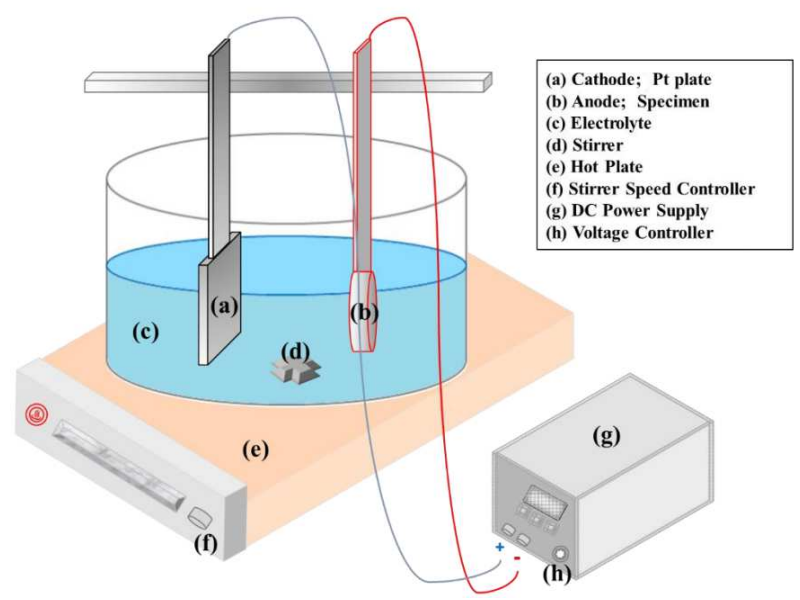

Fig. 1. Schematic diagram of the anodic oxidation apparatus.

\subsection{Potentiodynamic polarization test}

The degradation behavior and mechanical integrity of each specimen were determined using a potentiodynamic polarization test to fully understand their electrochemical corrosion behavior. The analysis was performed in 
$0.9 \% \mathrm{NaCl}$ electrolyte solution buffered at $\mathrm{pH} 7.41$ at $36.5 \pm 1{ }^{\circ} \mathrm{C}$ in a flat cell that included $300 \mathrm{~mL}$ of Tassimulated body fluid (Tas-SBF) solution using a PARSTAT 2273 potentiostat/galvanostat apparatus (Princeton Applied Research, USA) (Table II). The specimens sized at $10 \times 10 \mathrm{~mm}^{2}\left(1.0 \mathrm{~cm}^{2}\right.$ of exposed area) were used for the degradation test. Prior to testing, a potentiodynamic curve was obtained from the stabilization process by performing an open circuit that removes dissolved oxygen in solution by inserting argon gas for an hour (deoxygenation). After hydrogen evolution testing (see Sect. 2.5 below), the surface of each specimen was coated with platinum using an E-1030 Ion Sputter device (Hitachi, Japan) and was observed on field emission scanning electron microscopy (FE-SEM) using a model S-4700 microscope (Hitachi, Japan). For the elemental analysis of specific areas of each specimen, energy dispersive spectroscopy (EDS) was carried out using the Xflash Detector 5030 (Bruker Nano, Germany). The test was performed under the conditions summarized in Table III.

TABLE II

Ion concentrations of Tas-simulated body fluid (SBF) and human blood plasma.

\begin{tabular}{c|c|c|c|c|c|c|c|c}
\hline \hline \multirow{2}{*}{\begin{tabular}{c} 
Solution \\
\cline { 2 - 8 }
\end{tabular}} & $\mathrm{Na}^{+}$ & $\mathrm{K}^{+}$ & $\mathrm{Ca}^{2+}$ & $\mathrm{Mg}^{2+}$ & $\mathrm{HCO}_{3}^{-}$ & $\mathrm{Cl}^{-}$ & $\mathrm{HPO}_{4}^{2-}$ & $\mathrm{SO}_{4}^{2-}$ \\
\hline $\begin{array}{c}\text { Simulated } \\
\text { body } \\
\text { fluid } \\
\begin{array}{c}\text { Human } \\
\text { blood } \\
\text { plasma }\end{array}\end{array}$ & 142.0 & 5.0 & 1.5 & 2.5 & 125.0 & 27.0 & 1.0 & 0.5 \\
& 142.0 & 5.0 & 2.5 & 1.5 & 27 & 103.0 & 1.0 & 0.5
\end{tabular}

TABLE III

Conditions of the electrochemical corrosion test.

\begin{tabular}{c|c}
\hline \hline & Potentiodynamic test \\
\hline Counter electrode & Platinum \\
Reference electrode & $\mathrm{Ag} \cdot \mathrm{AgCl} / \mathrm{KCl}$, saturated \\
Working electrode & Specimens \\
Scanning range & $-0.5 \sim 2 \mathrm{~V}$ \\
Scanning rate & $0.25 \mathrm{mV} / \mathrm{sec}$ \\
Electrolyte & $0.9 \% \mathrm{NaCl}$ \\
Temperature & $36.5 \pm 1^{\circ} \mathrm{C}$
\end{tabular}

\subsection{Hydrogen evolution test}

The hydrogen evolution test was carried out to collect hydrogen gas produced in vitro from the anodized pure $\mathrm{Mg}$ and $\mathrm{Mg}-x \mathrm{Ca}$ alloys $(x=0.5,1,5$ wt. $\%)$. The discshaped specimens were soaked in Tas-SBF solution (Table II) in a beaker equipped with a funnel and burette (Fig. 2). The rate of hydrogen emission from the specimens was measured during a 14-day immersion in TasSBF solution. After the immersion, each specimens was surface-coated with platinum using the sputter coating device and was observed on FE-SEM (as described in
Sect. 2.4). Energy dispersive spectroscopy was used for the component analysis of specific sites on the specimens (as described in Sect. 2.4).

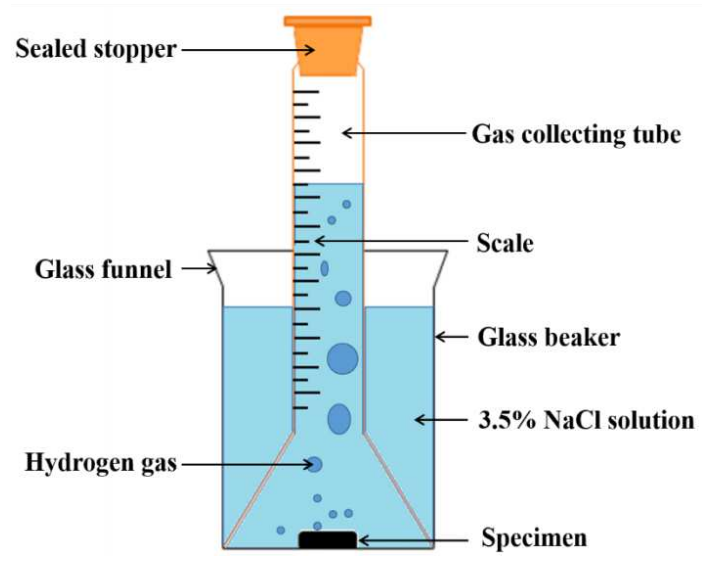

Fig. 2. Schematic illustration of hydrogen measurement test.

\subsection{Cell culture}

Ham's F12 Medium/Dulbecco's Modified Eagle's Medium (DMEM/F12) (Welgene, Korea) including $2.5 \mathrm{mM}$ L-glutamine and $15 \mathrm{mM}$ HEPES without phenol red supplemented with 10\% fetal bovine serum (Biotechnics Research, USA) and $0.3 \mathrm{mg} / \mathrm{ml}$ geneticin 418 (Welgene, Korea) were added to each culture after the adhesion of human fetal osteoblastic cell line (hFOB) 1.19 cells (CRL-11372 ${ }^{\mathrm{TM}}$, American Type Culture Collection, USA). For optimal cell proliferation, the culture medium was exchanged every 3 days. When the cells reached dense growth, the agar was removed from the culture plate and washed with phosphate-buffered saline (PBS) (Welgene, Korea), and the adherent cells were released using $0.05 \%$ single-strength Trypsin-EDTA 1X (Gibco, Canada) during a 3-5 minute incubation period at $37^{\circ} \mathrm{C}$ in an atmosphere of $5 \% \mathrm{CO}_{2}$. The released cells were collected using $1 \mathrm{~mL} \mathrm{DMEM} / \mathrm{F}-12$ and were centrifuged for 5 minutes at $2000 \mathrm{rpm}$. The supernatant was discarded and the cell pellets were collected for successive culture and use. Third to sixth generation osteoblasts were used in this study.

\subsection{Biological evaluation of cell proliferation}

Before the cell proliferation experiment, every specimen was sterilized by ethylene oxide gas. Five specimens of each group were placed in wells of a 24-well plate for preparation. The $500 \mu \mathrm{L}\left(1 \times 10^{5}\right.$ cells $\left./ \mathrm{mL}\right)$ of cultivated hFOB 1.19 was added to each well of the prepared specimens and incubated for 1 and 3 days at $37^{\circ} \mathrm{C}$ in an atmosphere of $5 \% \mathrm{CO}_{2}$. At each time, $50 \mu \mathrm{L}$ of EZ-Cytox reagent (Itsbio, Korea) were added to each well and incubation was continued under the same conditions for 30 minutes. After an orange color developed during the subsequent reaction, $100 \mu \mathrm{L}$ aliquots were dispensed into 
the wells of a 96-well plate, and any bubbles were eliminated according to the instructions of the manufacturer. The absorbance at $450 \mathrm{~nm}$ of each well was measured and compared to the reference wavelength of $630 \mathrm{~nm}$ using an ELx 800UV ELISA reader (Bio-Tek Instruments, USA).

\subsection{Microscopic evaluation of cell adhesion}

The cells were prepared and incubated for 1 and 3 days as described in Sect. 2.6, and samples were fixed with $2.5 \%$ glutaraldehyde for 2 hours for FE-SEM examination. After being washed three times, for 10 minutes each, using PBS, the samples were dehydrated for 15 minutes in a series of graded ethanol solutions (40\%, 50\%, $60 \%, 70 \%, 80 \%$, and 90\%) three times for 10 minutes in $100 \%$ ethanol. The dehydrated samples were dried in a $37^{\circ} \mathrm{C}, 5 \% \mathrm{CO}_{2}$ incubator. Each dried specimen was coated with platinum E-1030 Ion Sputter (Hitachi, Japan) for 60 seconds using a 108 Auto-Sputter Coater (Cressington Scientific Instruments, England). The degree of adhesion was observed on FE-SEM.

\subsection{Statistical analysis}

IBM SPSS Statistics version 21 software (SPSS, Chicago, IL, USA) was used for statistical analyses, and the Kruskal-Wallis test was used to test for significance among the test groups. Statistical significance was apparent as $p<0.083$.

\section{Results and discussion \\ 3.1. Potentiodynamic test}

To evaluate the corrosion behaviors of anodized pure $\mathrm{Mg}$ and the $\mathrm{Mg}-\mathrm{Ca}$ alloys, we used the potentiodynamic test to assess surface changes and the amount of hydrogen gas generated during immersion in Tas-SBF. Based on previous studies of potentiodynamic polarization, we have determined the corrosion potential of pure $\mathrm{Mg}$ to be -1.647 Vssc, which was lower than that of all three $\mathrm{Mg}-\mathrm{Ca}$ alloys. As the Ca content increased, the corrosive potential curve of the alloys displayed a tendency to increase (Fig. 3). The Mg-0.5Ca alloy polarization curve

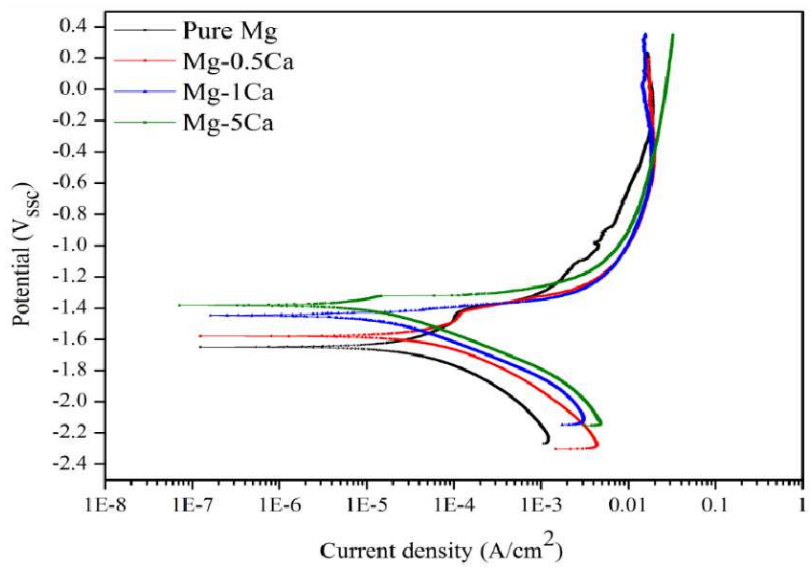

Fig. 3. Potentiodynamic polarization curves of anodized pure $\mathrm{Mg}$ and $\mathrm{Mg}-\mathrm{Ca}$ alloys in $0.9 \% \mathrm{NaCl}$ at $36.5 \pm 1{ }^{\circ} \mathrm{C}$. contained a stationary phase indicative of the formation of a passive film layer at the surface of the alloy during Tas-SBF immersion. No stationary phase was evident in the $\mathrm{Mg}-1 \mathrm{Ca}$ and $\mathrm{Mg}-5 \mathrm{Ca}$ binary alloy curves, most likely a reflection of decreasing cathode current density and hydrogen generation ratio [26]. The $\mathrm{Mg}-5 \mathrm{Ca}$ alloy had the highest corrosion potential of all three alloys, with pure $\mathrm{Mg}$ having the lowest. With the addition of $5 \mathrm{wt} . \% \mathrm{Ca}$, the current density (corrosion rate) displayed a decreasing trend, and the $\mathrm{Mg}-5 \mathrm{Ca}$ alloy showed increasing corrosion potential and decreasing current density. These changes improve corrosion resistance [36]. Consequently, because of decreasing particle size, the added Ca stacks as a precipitate on the grain boundary, acting as a barrier to corrosion and thus increasing corrosion resistance [37].

\subsection{Amount and rate of hydrogen emission}

The graphs in Figs. 4 and 5 show the amount and rate of hydrogen emission from the specimens in Tas-SBF at $36.5 \pm 1{ }^{\circ} \mathrm{C}$ for 14 days (324 hours) and allowed us to evaluate the stability of the alloys and their initial corrosion rates. The $\mathrm{Mg}-5 \mathrm{Ca}$ alloy had the lowest hydrogen generation rate, as compared with the other two alloys.

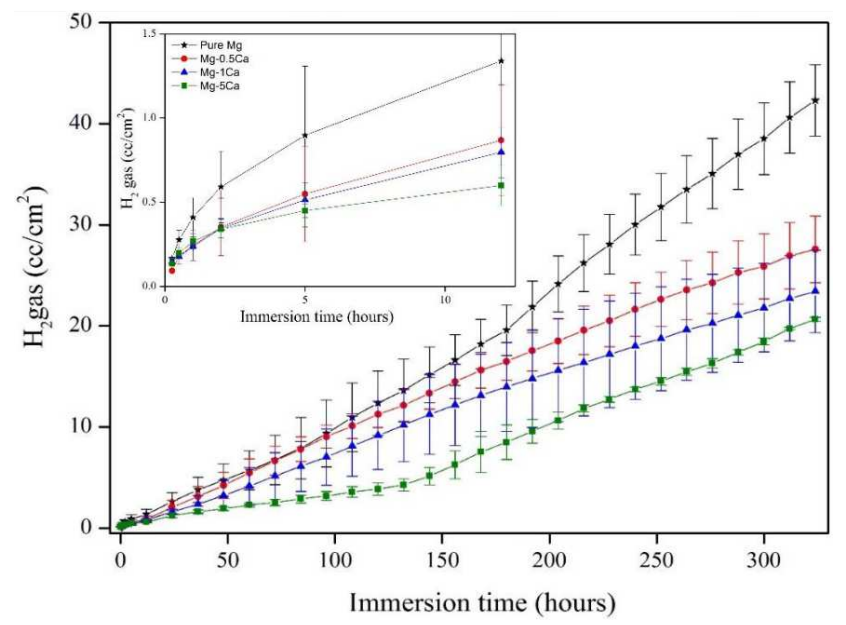

Fig. 4. Amount of hydrogen gas emitted during the 14-day immersion in Tas-SBF.

Formation of a chemically passive layer weakens the exchange current and hydrogen generation, which can inhibit the formation of $\mathrm{Mg}_{2} \mathrm{Ca}$ and stabilize the protective layer on the surface. The decreased Ca crystal grain size in the $\mathrm{Mg}-5 \mathrm{Ca}$ alloy and the formation of $\mathrm{Mg}_{2} \mathrm{Ca}$, are important factors that affect the size and distribution of the secondary phase and reduce the rate of hydrogen generation [36].

\subsection{SEM and EDS analyses after hydrogen emission}

Figure 6 shows representative SEM images of the corrosion products formed on the surface of the pure $\mathrm{Mg}$ and $\mathrm{Mg}-\mathrm{Ca}$ alloys after 14 days of immersion. After the hydrogen generation experiment, three phases $(\mathrm{Ca}, \alpha-\mathrm{Mg}$, and $\mathrm{Mg}_{2} \mathrm{Ca}$ ) have formed as large white and small grey 


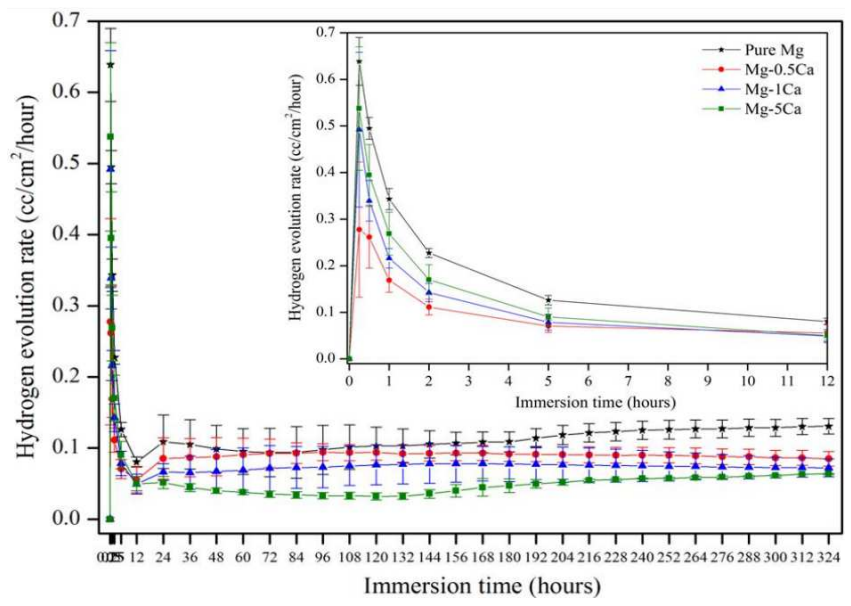

Fig. 5. Hydrogen evolution rate of anodized pure $\mathrm{Mg}$ and Mg-Ca alloys during Tas-SBF immersion.

irregular layers of corrosion products on the alloy surfaces. The corrosion products consisted mostly of a thin layer of $\mathrm{MgO}$ and $\mathrm{Mg}(\mathrm{OH})_{2}$, which correlated with a high exchange current in and on the surface of the Tas-SBF solution. Also, the $\mathrm{Mg}-5 \mathrm{Ca}$ alloy, which possessed the $\mathrm{Mg}_{2} \mathrm{Ca}$ secondary phase, easily destroyed the $\mathrm{Mg}(\mathrm{OH})_{2}$ passive state layer, accelerating the emission of $\mathrm{Mg}^{2+}$ and continuously reacting with $\mathrm{Cl}^{-}$to create $\mathrm{MgCl}_{2}[36]$.

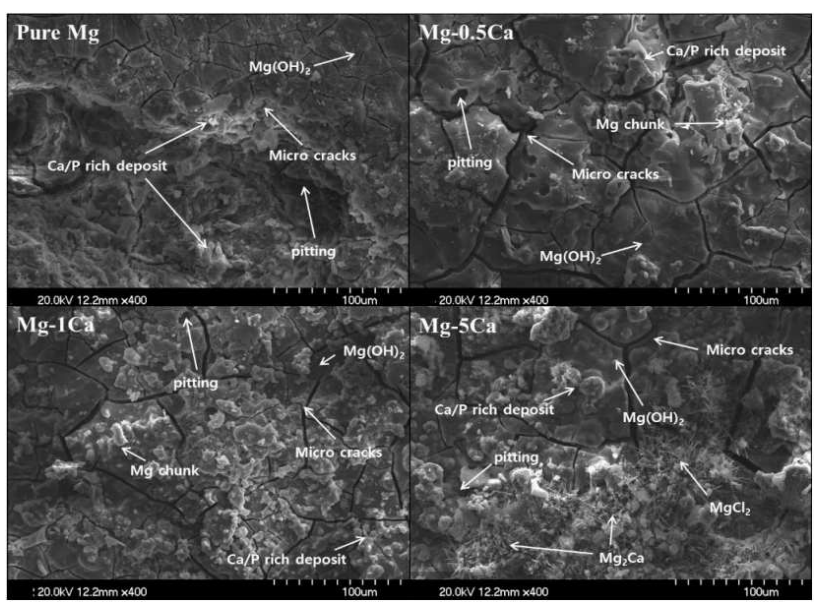

Fig. 6. SEM images showing morphology of anodized pure $\mathrm{Mg}$ and the three $\mathrm{Mg}-\mathrm{Ca}$ alloys.

\subsection{Biological assessment of cell proliferation}

To analyze the influence of $\mathrm{Ca}$ in anodized specimens of pure $\mathrm{Mg}$ and the $\mathrm{Mg}-\mathrm{Ca}$ alloys on osteoblast proliferation, we have assessed five replicates using the XTT cell proliferation assay. Results were obtained after incubating the 24-well plate with the specimens and $1 \times 10^{5}$ cells $/ \mathrm{mL}$ of $\mathrm{hFOB}$ cells at $37^{\circ} \mathrm{C}$ in a $5 \% \mathrm{CO}_{2}$ atmosphere for 1 and 3 days (Fig. 7). Pure $\mathrm{Mg}$ and all three $\mathrm{Mg}-\mathrm{Ca}$ alloys showed a linear increase depending on Ca content both, on both days. The cell viability of pure

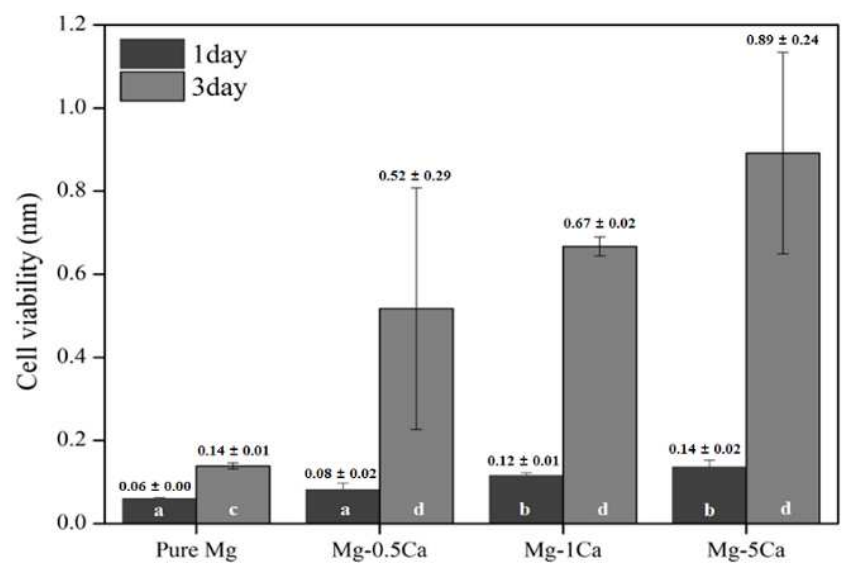

Fig. 7. Cellular viability during culture of osteoblast cells on surfaces of treated pure $\mathrm{Mg}$ and $\mathrm{Mg}-\mathrm{Ca}$ alloys. $\mathrm{a}-\mathrm{d}$ : identical letters indicate that the values are not statistically different $(p<0.083)$.

$\mathrm{Mg}$ samples was markedly lower than that of other three alloys. $\mathrm{Mg}$ releases hydrogen gas during corrosion, which makes the surrounding solution alkaline. This environment is not suitable for cell growth. Therefore, as corrosion slows with $\mathrm{Ca}$ addition, cell proliferation increases proportionally. Thus, the addition of Ca reinforces corrosion resistance and increases the cell proliferation rate.

\subsection{Microscopic assessment of cell adhesion}

After incubating the 24-well plate that contained the specimens and $1 \times 10^{5}$ cells $/ \mathrm{mL}$ of hFOB cells, as described in Sect. 3.4, the surfaces of the anodized pure $\mathrm{Mg}$ and $\mathrm{Mg}-\mathrm{Ca}$ alloys were observed on SEM to confirm the adhesion of osteoblasts (Figs. 8 and 9). Ca-containing phosphate is known to improve the osteoconductivity and biocompatibility of $\mathrm{Mg}$ alloys [38]. The cells were sparsely attached to the Mg-containing surfaces, because of the formation of hydrogen gas and the increased $\mathrm{pH}$; however, the cells have attached well to the surfaces of the Ca-containing alloys. As the $\mathrm{Ca}$ content of the alloys increased, the cells proliferated and were spindleshaped and displayed closer attachment, indicating that the Ca-containing alloys enhanced the osteoconductivity and positively affected the biocompatibility of the $\mathrm{Mg}$ alloys.

\section{Conclusions}

In this study, we evaluated the effect of different $\mathrm{Ca}$ contents of anodized $\mathrm{Mg}-x \mathrm{Ca}$ alloys $(x=0.5,1,5$ wt. $\%$ ) to determine surface absorption rate in vitro. The addition of $\mathrm{Ca}$ has increased the amount of precipitate that accumulated at the grain boundaries and acted as a barrier to corrosion, consequently improving the corrosion resistance. As immersion time and Ca content increased, a chemically passive layer had formed, suppressing the emission of hydrogen gas and reducing the rate of hydrogen generation. With the addition of $\mathrm{Ca}$, corrosion 


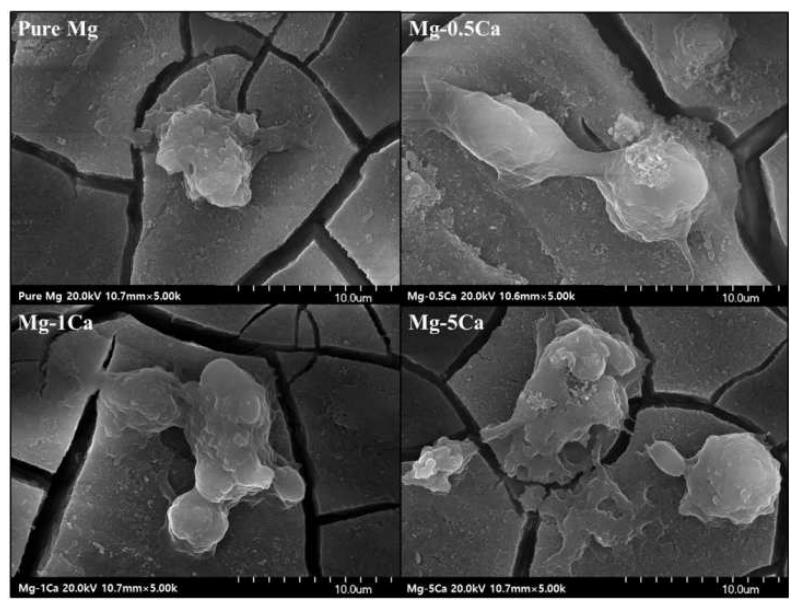

Fig. 8. SEM images showing hFOB cells attached to the surfaces of the specimens after 1day of cultivation.

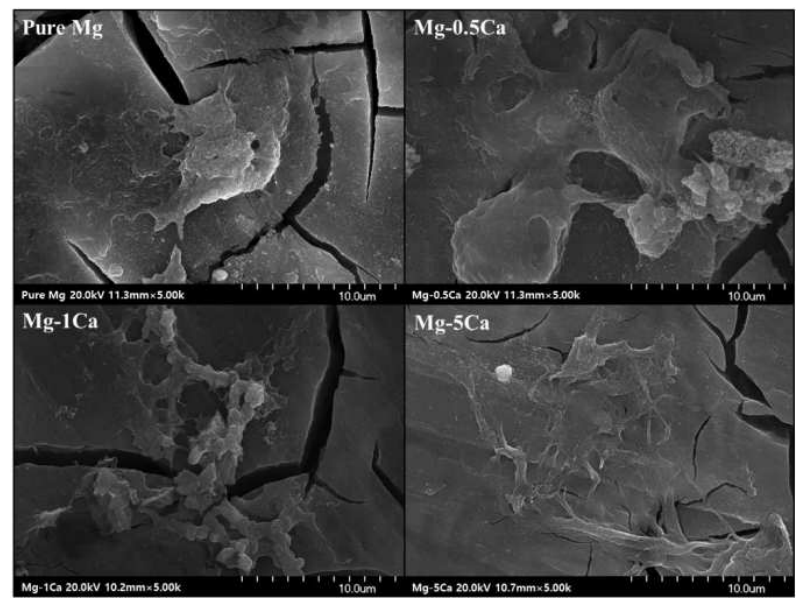

Fig. 9. SEM images showing hFOB cells attached to the surfaces of the specimens after 3days of cultivation.

resistance was reinforced and cell survival was increased. Alloys containing Ca have enhanced osteoconductivity, rendering the $\mathrm{Mg}$ alloys markedly more biocompatible. Anodized pure $\mathrm{Mg}$ and $\mathrm{Mg}-\mathrm{Ca}$ alloys exhibited improved corrosion resistance with the increasing Ca contents, enabling control of the dissolution speed and indicating the applicability of these binary alloys as biodegradable material.

This study confirms that the addition of Ca helps to form a protective film on the alloys. The rate of hydrogen emission by the $\mathrm{Mg}-5 \mathrm{Ca}$ alloy was lower than that of the other groups. Depending on the Ca content, the anodized Mg used in dental implants would be expected to be bioavailable in vivo. Because the $\mathrm{Mg}-5 \mathrm{Ca}$ alloy has corrosion resistance and biocompatibility, this alloy is likely to become important in various metabolic activities in human bone. However, since the exact mechanism and alloy quantitative analysis are not clear, further studies will be required to elucidate the biomedical functions of $\mathrm{Mg}$.

\section{Acknowledgments}

This research was supported by Basic Science Research Program through the National Research Foundation of Korea (NRF) funded by the Ministry of Education, Science and Technology (NRF-2012R1A1A1043434).

\section{References}

[1] H.K. Seok, Y.C. Kim, P.R. Cha, G.S. Han, Y.Y. Kim, S.Y. Cho, S.J. Yang, Korean J. Met. Mater. 22, 29 (2009).

[2] Y. Song, S. Zhang, J. Li, C. Zhao, X. Zhang, Acta Biomater. 6, 1736 (2010).

[3] H.G. Seiler, H. Sigel, A. Sigel, Handbook on Toxicity of Inorganic Compounds, Marcel Dekker 1988.

[4] R.J. Elin, Clin. Chem. 33, 1965 (1987).

[5] H. Zreiqat, C.R. Howlett, A. Zannettino, P. Evans, G. Schulze-Tanzil, C. Knabe, M. Shakibaei, J. Biomed. Mater. Res. 62, 175 (2002).

[6] M.P. Staiger, A.M. Pietak, J. Huadmai, G. Dias, Biomaterials 27, 1728 (2006).

[7] E.P.D. Garmo, J.T. Black, R.A. Kohser, DeGarmo's Materials and Processes in Manufacturing, John Wiley \& Sons 2011.

[8] L.J. Gibson, M.F. Ashby, Cellular Solids: Structure and Properties, Cambridge University Press 1997.

[9] J.W. Choi, Y.M. Kong, H.E. Kim, I.S. Lee, J. Am. Ceram. Soc. 81, 1743 (1998).

[10] T. V. Thamaraiselvi, S. Rajeswari, Trends Biomater. Artif. Organs. 18, 9 (2004).

[11] F. Witte, V. Kaese, H. Haferkamp, E. Switzer, A. Meyer-Lindenberg, C.J. Wirth, H. Windhagen, Biomaterials 26, 3557 (2005).

[12] C.E. Wen, M. Mabuchi, Y. Yamada, K. Shimojima, Y. Chino, T. Asahina, Scr. Mater. 45, 1147 (2001).

[13] H. Wang, Z.M. Shi, K. Yang, Adv. Mater. Res. 32 , 207 (2008).

[14] H.Y. López, D.A. Cortés-Hernández, S. Escobedo, D. Mantovani, Key Engin. Mater. 309, 453 (2006).

[15] J.H. Ji, Y.K. Kim, I.S. Park, H.H. Park, T.S. Bae, M.H. Lee, Korean Soc. Dent. Mater. 39, 26 (2012).

[16] R.B. Figueiredo, T.G. Langdon, J. Mater. Sci. 44, 4758 (2009).

[17] C.C. Koch, R.O. Scattergood, K.M. Youssef, E. Chan, Y.T. Zhu, J. Mater. Sci. 45, 4725 (2010).

[18] B. Denkena, F. Witte, C. Podolsky, A. Lucas, Proc. 5th Euspen Int., 2005, p. 233.

[19] S.G. Lee, Ph.D. Thesis, Pusan National University, 2012.

[20] Z. Li, X. Gu, S. Lou, Y. Zheng, Biomaterials 29, 1329 (2008).

[21] S.G. Steinemann, Corrosion of Surgical Implants-In Vivo and In Vitro Tests, John Wiley \& Sons, 1980.

[22] Y. Okazaki, S. Rao, T. Tateishi, Y. Ito, Mater. Sci. Eng. A 243, 250 (1998).

[23] K. Feser, M. Kietzmann, W. Baumer, C. Krause, F.W. Bach, J. Biomater. Appl. 25, 685 (2010). 
[24] A. Krause, N. von der Höh, D. Bormann, C. Krause, F.W. Bach, H. Windhagen, A. Meyer-Lindenberg, J. Mater. Sci. Mater. Med. 45, 624 (2010).

[25] F. Witte, Acta Biomater. 6, 1680 (2010).

[26] A. Zakiyuddin, M.Sc. Thesis, Chonnam National University, 2014.

[27] N.T. Kirkland, N. Birbilis, M.P. Staiger, Acta Biomater. 8, 925 (2012).

[28] C. Lorenz, J.G. Brunner, P. Kollmannsberger, L. Jaafar, B. Fabry, S. Virtanen, Acta Biomater. 5, 2783 (2009).
[29] K.J. Park, M.W. Jung, J.H. Lee, J. Microelectronics Packaging Soc. 17, 71 (2010).

[30] M.H. Kim, Ph.D. Thesis, Pukyong National University, 2010.

[31] D.K. Lee, M.Sc. Thesis, Pusan National University, 2010.

[32] P.B. Srinivasan, C. Blawert, W. Dietzel, Mater. Sci. Eng. A 494, 401 (2008).

[33] Y. Zhang, C. Yan, F. Wang, H. Lou, C. Cao, Surf. Coat. Technol. 161, 36 (2002). 
[34] H. Duan, K. Du, C. Yan, F. Wang, Electrochim. Acta 51, 2898 (2006).

[35] R. Kartika, M.Sc. Thesis, Yeungnam University, 2007.

[36] Q. Zhao, X. Guo, X. Dang, J. Hao, J. Lai, K. Wang, Colloids Surf. B. Biointerfaces 102, 321 (2013).

[37] Y. Li, P.D. Hodgson, C. Wen, J. Mater. Sci. Mater. Med. 46, 365 (2011).
[38] S. Zhang, J. Li, Y. Song, C. Zhao, X. Zhang, C. Xie, Y. Zhang, H. Tao, Y. He, Y. Jiang, Y. Bian, Mater. Sci. Eng. C 29, 1907 (2009). 